\title{
Aspects of the Population biology of Common Carp, Cyprinus carpio (Linnaeus, 1758)
}

\section{In Lake Naivasha, Kenya}

\author{
${ }^{1}$ Eunice Mutethya, ${ }^{2}$ Edwine Yongo,,${ }^{3}$ Cishahayo Laurent, ${ }^{4}$ Edna Waithaka \& \\ ${ }^{5}$ Evans Lomodei \\ ${ }^{I}$ Department of Fisheries \& Aquatic Sciences, University of Eldoret, Eldoret, Kenya \\ ${ }^{2}$ Faculty of Life and Pharmaceutical Sciences, Hainan University, China \\ ${ }^{3}$ Faculty of Agricultural and forestry economic management, Hainan University, China \\ ${ }^{4}$ Kenya Marine \& Fisheries Research Institute (KMFRI), Naivasha Station, Kenya \\ ${ }^{5}$ Department of Environmental Science, Turkana University College, Lodwar, Kenya.
}

\begin{abstract}
The Common carp, Cyprinus carpio is an exotic fish in Lake Naivasha. It is one of the commercially important species in the lake. This study investigated on its biology and population parameters during 2017. Fish samples (433) were caught using gillnets of mesh-sizes 2-5 inches. Length of fish ranged from 12.0 to $69.0 \mathrm{~cm}$ TL, and weighed between 32 and $6840 \mathrm{~g}$. The overall population sex ratio was 1.66: 1.0 (male: female). The mean length of females was $34.8 \mathrm{~cm}$ and males $32.1 \mathrm{~cm}$. The length at first maturity was calculated at 54.0 and $49.0 \mathrm{~cm}$ for females and males, respectively. The mean condition factor for all fish was 1.05 . The peak condition values were recorded during April (1.35), September (1.59) and October (1.80). There was a significant difference in mean condition factor within the size classes highest (1.38) and lowest (0.93) values recorded in class 56-60 and 26-30, respectively. The overall asymptotic length $(L \infty)$ was $73.5 \mathrm{~cm}$ and growth curvature $(K) 1.05 \mathrm{yr}^{-1}$ with growth performance index $(\Phi)$ of 3.72. The total $(Z)$, natural $(M)$, fishing $(F)$ mortality coefficients $2.85,1.34$ and $1.78 \mathrm{yr}^{-1}$, respectively. The exploitation rate $(E)$ of 0.57 was higher than optimum sustainable yield $\left(E_{0.5}\right)$ of 0.32 , but not different from maximum sustainable yields (Emax) 0.54 and economic yield $\left(E_{0.1}\right)$ 0.46. The length at first capture $\left(\mathrm{L}_{\mathrm{C} 50}\right)$ was lower than length at first maturity $\left(\mathrm{L}_{\mathrm{M} 50}\right)$, suggesting capture of immature fish. This study provides parameters of fish biology and population often useful in fisheries management.
\end{abstract}

Keywords: growth, mortality, maturity, condition, sex ratio 


\section{Introduction}

Common carp, Cyprinus carpio belongs to the class Osteichthyes (Bony fishes) of the order Cypriniformes and family Cyprinidae. It is a fresh water fish that lives in pools, lakes, streams and reservoirs with temperatures range of $23^{\circ} \mathrm{C}$ to $30^{\circ} \mathrm{C}$. The fish is native to the Ponto-Caspian region, but has been introduced into several freshwater ecosystems world-wide (Vilizzi et al. 2015). It is listed amongst the world's worst 100 invasive alien species (Lowe et al. 2000), thus controlling its populations is a high priority in many countries. Its invasive success is attributed to its diverse feeding strategies, high growth rate, high environmental tolerance and early sexual maturation (Winker et al. 2011; Vilizzi and Copp, 2017). Cyprinus carpio is a benthic omnivore, feeding majorly on benthic macro invertebrates and zooplanktons (Rahman et al., 2006). It disturbs the bottom sediment while feeding that increases water turbidity and nutrient enrichment thus impacting environmental conditions. It matures at the age of 3-6 months in tropical systems, but can take up to 3-5 years in temperate environments to mature (Adamek \& Pistelok, 1991) Cyprinus carpio normally spawns in early summer and spring but it can also breed in all year round in the tropics (Oyugi et al. 2011). Each female fish can produce about 360,000 to 599,000 eggs (Froese \& Pauly, 2002).

Cyprinus carpio was accidentally introduced into Lake Naivasha in 1999 (Hickley et al., 2004). Before the introduction, Lake Naivasha originally contained only the endemic Black lamprey Aplocheilichthys antinorii that was last recorded in 1962 and is believed to have gone extinct probably due to effects of the introductions (Elder et al. 1971). Other fish species currently present in the lake includes; Nile Tilapia (Oreochromis niloticus), Blue-spotted tilapia (O. leucostictus), Tilapia Graham (O. esculentus), Red-belly Tilapia (Tilapia zilli), Largemouth bass (Micropterus salmoides), Crayfish (procambrus clarkii) and the African catfish (Clarius gariepinus) (Hickley et al. 2004; Ojuok et al. 2007). However, landing statistics from 2015 onwards have shown decline in catches of which the fishery is presently dominated by $O$. niloticus (64\%), C. carpio (35\%) and C. gariepinus (1\%), with the other species contributing less than $0.1 \%$ of the total catch (Njiru et al., 2017). Lake Naivasha faces considerable pressures including habitat degradation, major fluctuations in water level resulting from climatic factors and anthropogenic activities. The decline in catches may be attributable to the interactions between multiple exotic species, increase in fishing effort and changes in the lake water levels 
(Keyombe et al. 2017). This study, thus investigated the biological and population parameters of C. carpio in Lake Naivasha in light of the increasing fishing pressure and the changing environmental condition. Such data is presently limited in the lake, though useful in managing the fishery.

\section{Materials and methods}

\section{Study area}

Lake Naivasha is a freshwater body located in the Eastern arm of Great Rift Valley, Kenya at $00^{\circ}$ $46^{\prime} \mathrm{S} ; 36^{\circ} 22^{\prime} \mathrm{E}$ and lies at an altitude of $1890 \mathrm{~m}$ (Fig. 1). It is a small endorheic lake of approximately $145 \mathrm{~km}^{2}$ with a catchment area of about $3,200 \mathrm{~km}^{2}$, and the second largest freshwater body after Lake Victoria's Kenyan gulf (Hickley et al, 2008). Its mean depth varies between $4 \mathrm{~m}$ and $6 \mathrm{~m}$. The lake is fed by the perennial Malewa and Gilgil rivers with the former being the main one (Kitaka et al., 2002). It is characterized by high water levels (Oyugi et al. 2011) due to two wet seasons in the months of March-May (long rains) and October-November (short rains). Lake Naivasha is the major source of fish for the surrounding community and fresh water for the numerous horticultural industries in the area. This study was carried out in four sites within the lake (Fig.1). Crescent is isolated and characterized with sand-rock substrate; Hippo Point is open lake and deepest also have sand and rock substrate; Oserian Bay is semiisolated-shallow and has mud substrate; Korongo is shallow near shore characterized by papyrus. Fishing was conducted during January and December 2017 from each site. Fishing was not done in July due to bad weather conditions. Fish samples (433) were obtained using gillnets of meshsizes 2-5 inches which were deployed overnight for 12 hours and hauled in the morning next day. The fish caught were sorted and the species of $C$. carpio were measured (cm, TL) and weighed $(\mathrm{g})$. The specimens were dissected for determination of sex and maturity according to the scheme of Donkers (2004). 


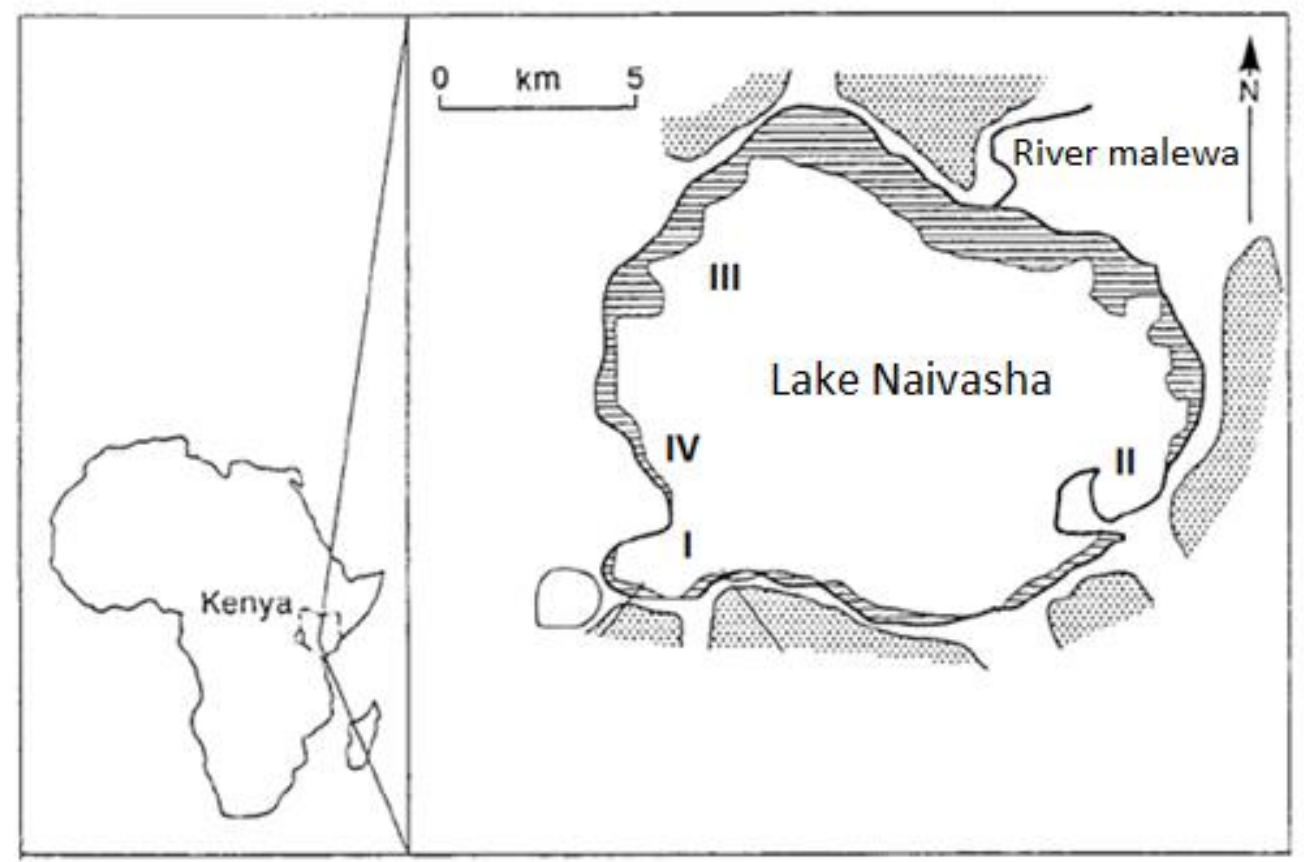

Figure 1: Map of Lake Naivasha, Kenya showing the study sites I (Oserian), II (Crescent), III (Korongo) and IV (Hippo point).

\section{Data analysis}

The relative condition factor was calculated as follows:

$$
K=\frac{W}{\left(a \times T L^{b}\right)}
$$

Average size at first maturity $\left(\mathrm{L}_{50}\right)$ referred to as size (total length) at which $50 \%$ of individuals in the fish population reach sexual maturity during the reproduction period. It was estimated by modeling the proportion of mature individuals to their respective length classes based on logistic function as follows.

$$
P=\frac{1}{1+e^{-a(L-b)}}
$$

Where $P=$ proportion of mature fish by length class, $L=$ total length class, $a$ and $b$ are model parameter estimates of which $b=L_{50}$ 
Chi-square $\left(\chi^{2}\right)$ was used to test for the difference in population sex ratio. T-test statistics was used to test for the difference in mean length and weight between male and female fish. One-way ANOVA was used to test for the variation in mean length and weight of the fish across the sites and months with Turkey LSD for pair-wise multiple comparisons. Kruskal-Wallis was used to test for the difference in fish condition factor in relation to sex, sites and months.

Data analysis for the population parameters was based on length-frequency distribution analysis using the Electronic Length Frequency Analysis (ELEFAN I in FAO ICLRAM Stock Assessment Tool FiSAT) (Pauly 1987; Gayanilo et al. 1996) as described by Yongo et al. 2018.

Estimates of the growth parameters were based on the von Bertalanffy growth formula (VBGF), which is expressed as follows:

$$
L_{t}=L_{\infty}\left(1-\exp ^{-K\left(t-t_{0}\right.}\right)
$$

where $L_{t}=$ predicted length at age $t ; L_{\infty}=$ asymptotic length; $K=$ growth curvature; $t_{o}=$ age the fish would have been at zero length.

The total mortality $(\mathrm{Z})$ was estimated using a length-converted catch curve. The coefficient of natural mortality $(M)$ was estimated with $K$ (year $\left.{ }^{-1}\right), L_{\infty}(\mathrm{cm})$ and $T$ (mean annual water temperature of $24^{\circ} \mathrm{C}$ ), following Pauly's empirical formula (Pauly, 1980) as follows:

$$
\operatorname{Ln}(M)=-0.0152-0.279 \operatorname{Ln}\left(L_{\infty}\right)+0.6543 \operatorname{Ln}(K)+0.463 \operatorname{Ln}(T)
$$

The fishing mortality $(F)$ was computed from the relationship:

$$
F=Z-M
$$

The exploitation rate $(E)$ was calculated from the relationship:

$$
E=\frac{F}{Z}=\frac{F}{F+M}
$$

The growth performance index ( $\left.\varnothing^{\prime}\right)$ was computed, according to Pauly and Munro (1984):

$$
\emptyset^{\prime}=\operatorname{Ln}(K)+2\left(L_{\infty}\right)
$$

The probability of capture was obtained from the backward extrapolation of the length-converted catch curve, according to Pauly et al. (1984). Growth parameters $L_{\infty}$ and $K$ were used as inputs. 
The relative yield-per-recruit model was based on Beverton and Holt (1966) model. The options assuming knife-edge selection was utilized using probabilities of capture. $L_{C} / L_{\infty}$ and $M / K$ ratios as inputs.

\section{Results}

\section{Fish biology}

Overall, there was a significant difference in the population sex ratio 260 males and 157 females (sex ratio $=1.66: 1.00, \chi^{2}=25.74, \mathrm{p}<0.01$ ). The size of male $C$. carpio caught ranged from 12.0 to $66.0 \mathrm{~cm}$ TL and between 32 and $4310 \mathrm{~g}$ in total mass; whereas, females ranged from 17.0 to $69.0 \mathrm{~cm}$ TL and weighed between 36 and $6840 \mathrm{~g}$. The TL frequency distribution indicated the dominance of fish between 26.0 and $30.0 \mathrm{~cm}$ TL (Fig. 2). The length at first maturity was calculated at 54.0 and $49.0 \mathrm{~cm}$ for females and males, respectively. Mean total length of females $(34.8 \mathrm{~cm} \mathrm{TL})$ were significantly larger than males $(32.1 \mathrm{~cm} \mathrm{TL})(t=2.33$, d.f $=268, \mathrm{p}=0.02)$. Mean weight of females (1087 g) were also significantly heavier than males $(677 \mathrm{~g})(t=3.03$, d.f $=207, p=0.003$ ). There was a significant difference in the mean TL of $C$. carpio captured across the study sites $\left(\mathrm{F}_{3,430}=10.69, \mathrm{p}<0.001\right.$; Crescent $=30.2 \mathrm{~cm}$, Hippo Point $=20.2 \mathrm{~cm}$, Korongo $=$ $36.3 \mathrm{~cm}$ and Oserian $=35.3 \mathrm{~cm}$ ), with all pair-wise comparisons between sites significantly different from each other (LSD, $\mathrm{p}<0.05)$.

The size of male and female $C$. carpio did not differ significantly between sites, except at Oserian where female fish were significantly larger than males $(t=2.30$, d.f $=138, \mathrm{p}=0.023)$. Multiple comparisons by Turkeys LSD showed that fish caught in August, September and October was significantly larger in length than all the other months $\left(F_{10,421,0.05}=16.01, p<\right.$ 0.001). The highest $(48.8 \mathrm{~cm})$ and lowest $(25.8 \mathrm{~cm})$ mean length were recorded in September and January, respectively (Fig. 3). The monthly mean weight of all the fish caught showed that the fish were significantly heavier in September and October than in all other months $\left(F_{10,421,0.05}=\right.$ $33.11, \mathrm{p}<0.001)$. The highest mean weight was observed during September $(3237 \mathrm{~g})$, while the lowest value was recorded in January (228.9 g) shown in figure 4. 
The overall condition factor for all fish was 1.05 . The condition factor differed significantly within the study sites $(H=53.0$, d.f $=3, p<0.001)$, with the highest (1.191) and lowest $(0.830)$ values recorded at Oserian and Hippo Point, respectively. Overall, the condition factor varied significantly during the study months $(H=185.17$, d.f $=10, p<0.01)$. The peak condition values were observed during April (1.346), September (1.585) and October (1.799) shown in figure 5. However there was no significant difference $(\mathrm{H}=1.32$, d.f $=1, \mathrm{p}=0.251)$ in the mean condition factor between males (1.033) and females (1.083). There was a significant difference in condition factor within the size classes $\left(\mathrm{F}_{11,396,0.05}=5.78, \mathrm{p}<0.001\right)$. The highest $(1.377)$ mean condition was recorded in size class 56-60 followed by class 20-25 (1.201) and the least (0.933) in length class 26-30 (Fig. 6). More female C. carpio were mature during September (60\%) and October (40\%) shown in figure 7.

\section{Population parameters}

The asymptotic length $(L \infty)$ and growth curvature $(K)$ were estimated at $74.4 \mathrm{~cm} \mathrm{TL}$ and $1.1 \mathrm{yr}^{-1}$ (Powell-wetherall, Fig. 8) and at $72.3 \mathrm{~cm} \mathrm{TL}$ and $1.0 \mathrm{yr}^{-1}$ (ELEFAN), giving an overall of 73.5 $\mathrm{cm} \mathrm{TL}$ and $1.05 \mathrm{yr}^{-1}$, respectively. The growth performance index (Ф) was calculated at 3.72 . Total mortality coefficient was estimated at $2.58 \mathrm{yr}^{-1}$ (Jones and van Zalinge, Fig. 9a) and 3.12 $\mathrm{yr}^{-1}$ (Length-converted catch curve, Fig. 9b), giving an overall of $2.85 \mathrm{yr}^{-1}$. The natural mortality $(M)$, fishing $(F)$ mortality coefficients and exploitation rate $(E)$ were calculated at $1.34,1.78 \mathrm{yr}^{-}$ ${ }^{1}$ and 0.57 , respectively (Fig. 9b). The Beverton and Holt's relative yield-per-recruit model (Fig. $10)$ calculated indices at 0.32 for optimum sustainable yield $\left(E_{0.5}\right), 0.54$ for maximum sustainable yield $\left(E_{\max }\right)$ and 0.46 for economic yield $\left(E_{0.1}\right)$. Results of the probability of capture indicated at least $25 \%$ of fish of $19.7 \mathrm{~cm}$ TL, $50 \%$ of the fish of $23.9 \mathrm{~cm}$ TL and $75 \%$ of all fish of $28.1 \mathrm{~cm}$ $\mathrm{TL}$ are retained on encounter with the gear. 


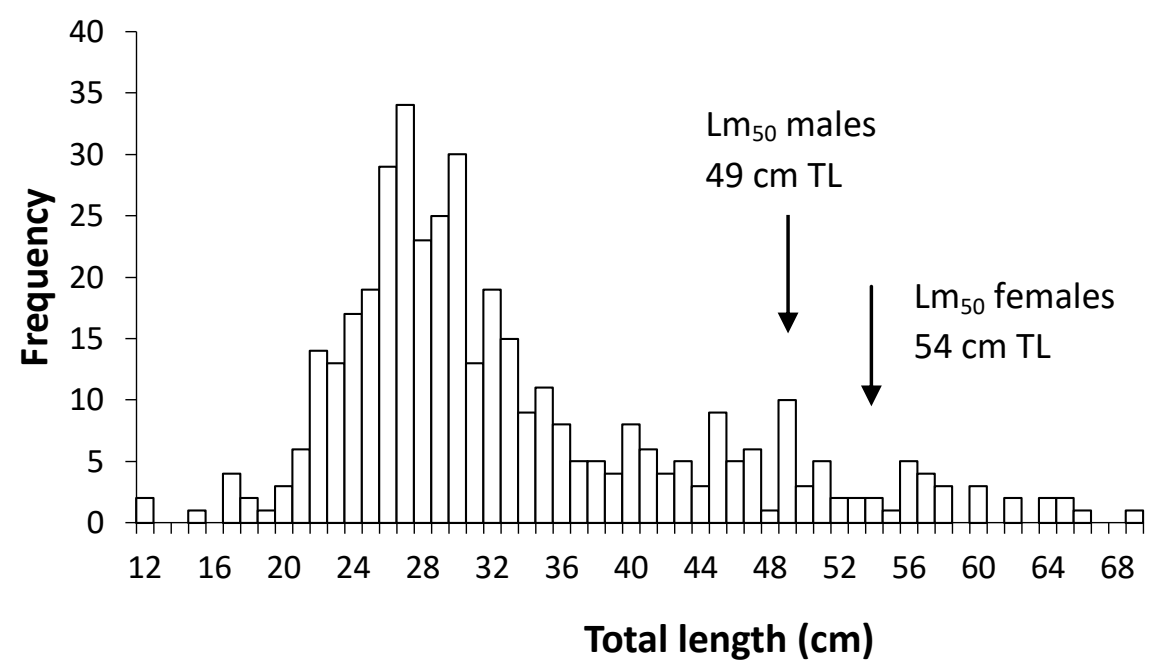

Figure 2: The total length (TL) frequency distribution of $C$. carpio caught in Lake Naivasha during the study period (2017). Vertical arrows indicate length at 50\% maturity $\left(\mathrm{Lm}_{50}\right)$.

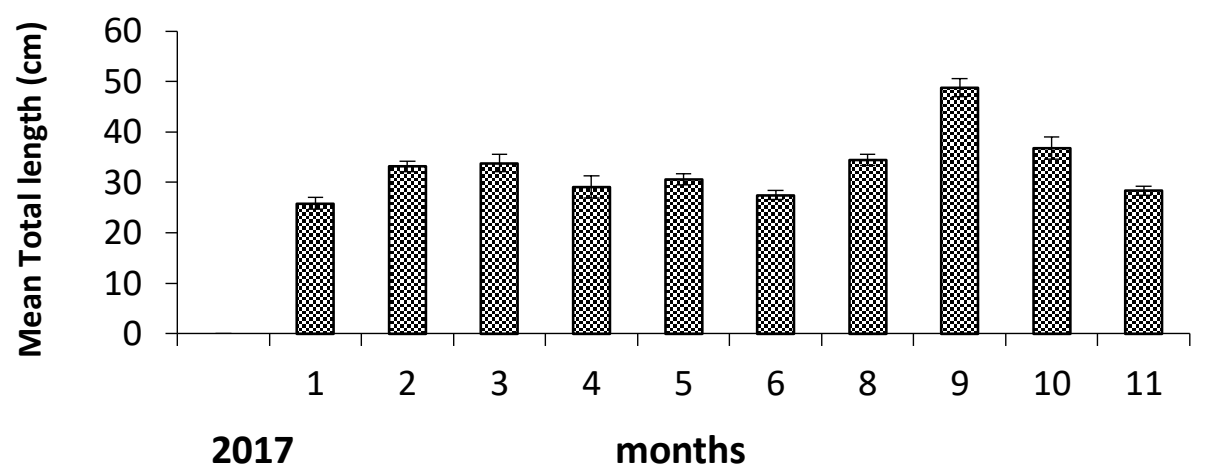

Figure 3: Monthly variation in mean TL of C. carpio caught in Lake Naivasha, 2017.

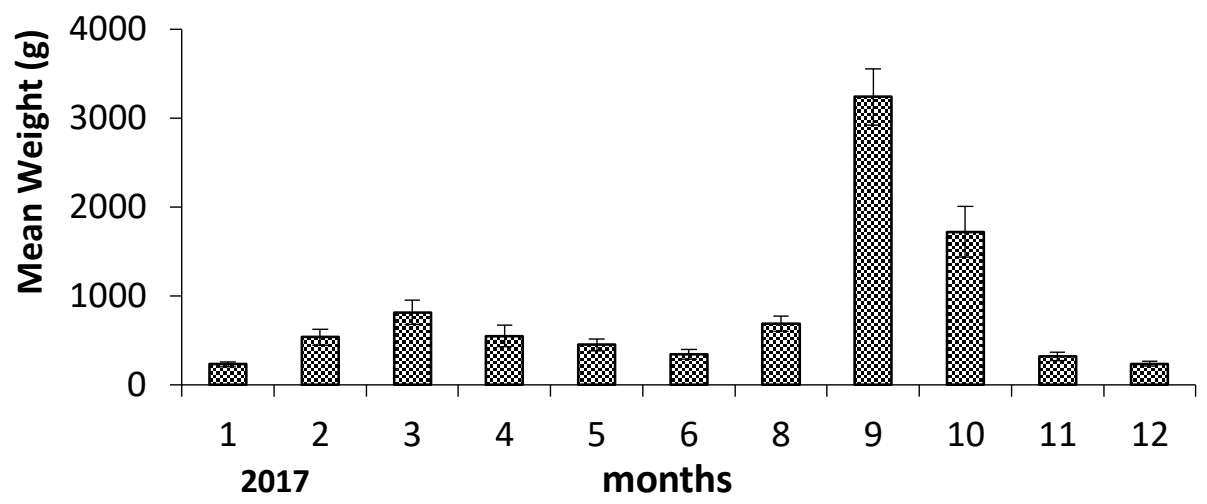

Figure 4: Monthly variation in mean weight of $C$. carpio caught in Lake Naivasha, 2017. 


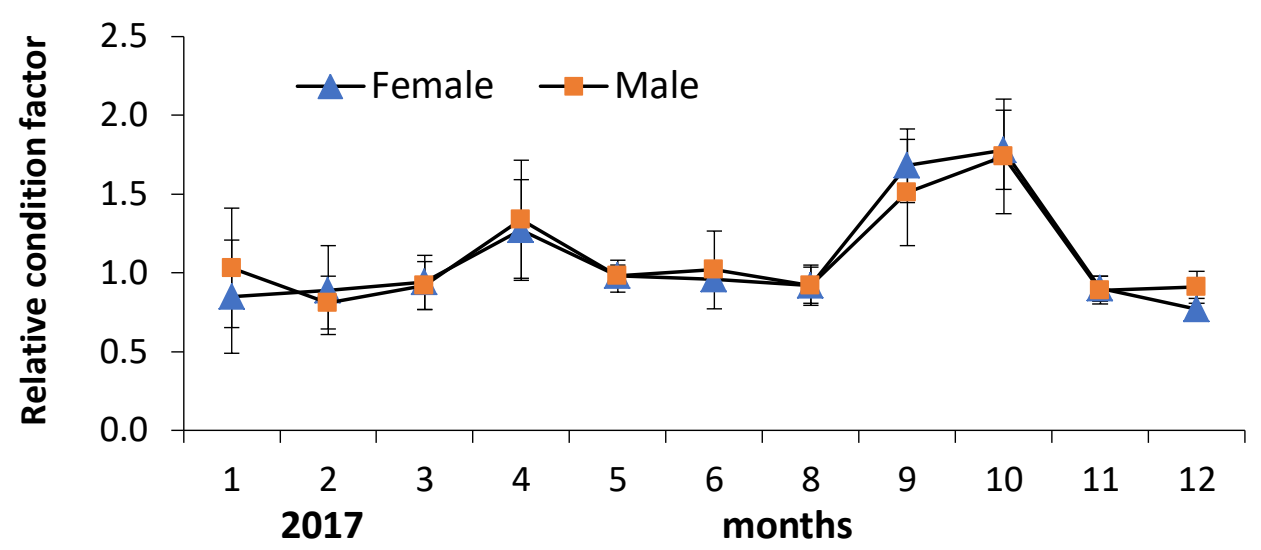

Figure 5: Monthly variation in mean relative condition factor of female and male C. carpio in Lake Naivasha, 2017.

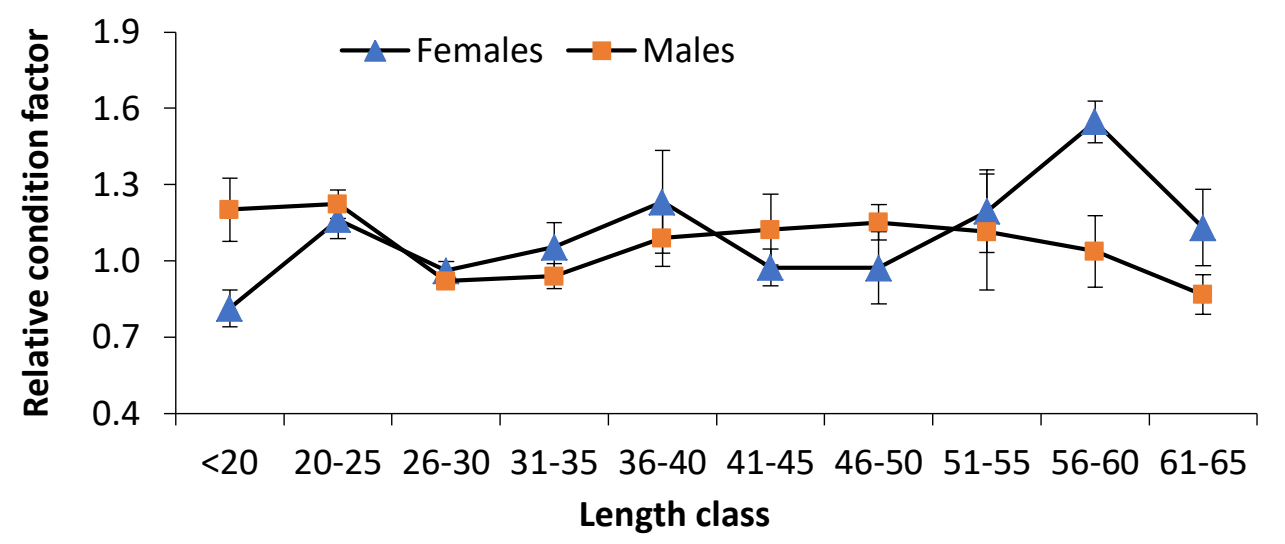

Figure 6: Size variation in mean relative condition factor of female and male C. carpio in Lake Naivasha, 2017.

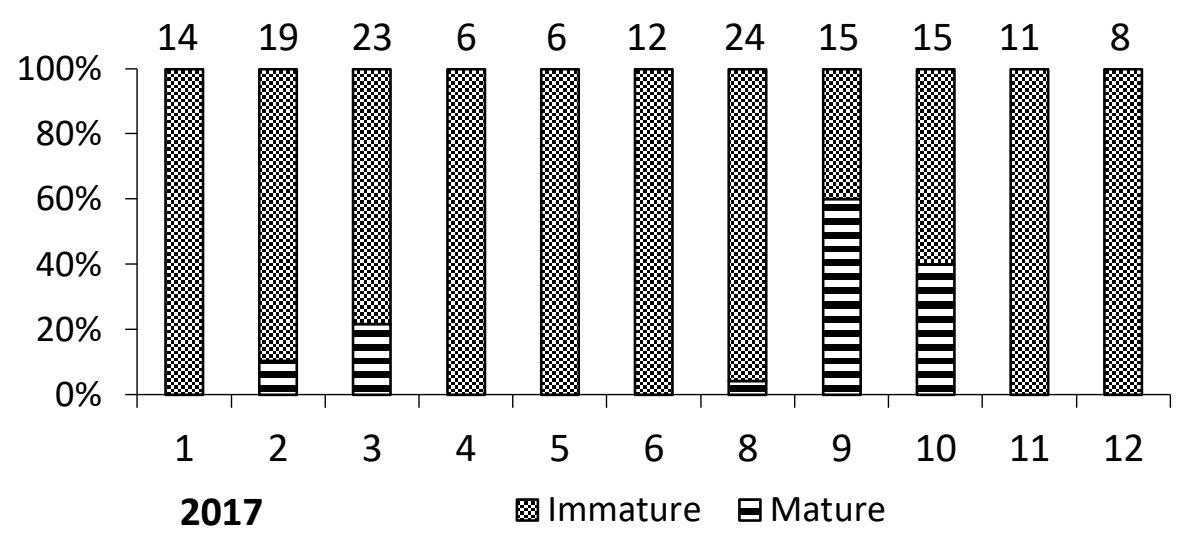

Figure 7: Monthly percent mature and immature female C. carpio in Lake Naivasha, 2017. 

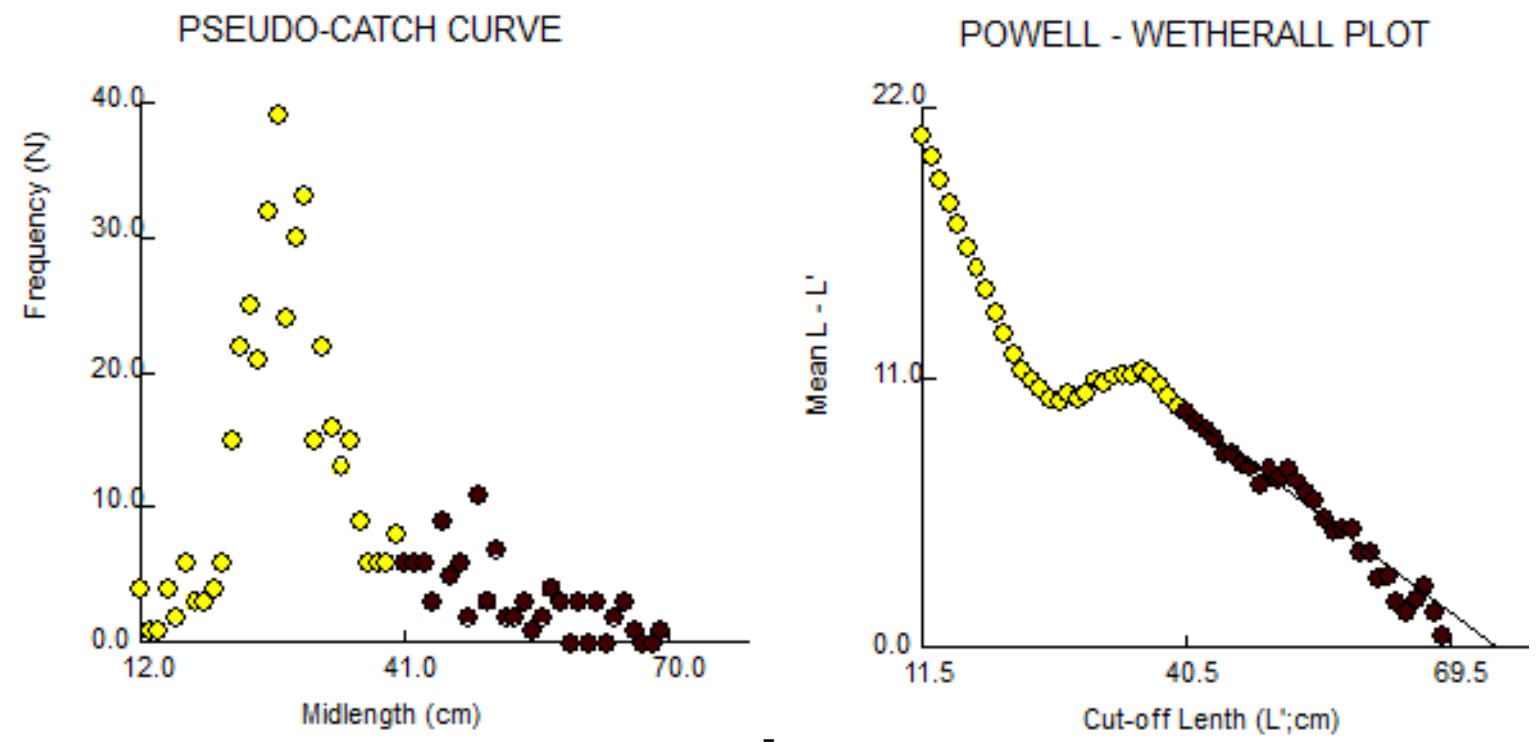

Figure 8: Powell-Wetheral plot estimating asymptotic length $(L \infty)$ and growth curvature $(K)$
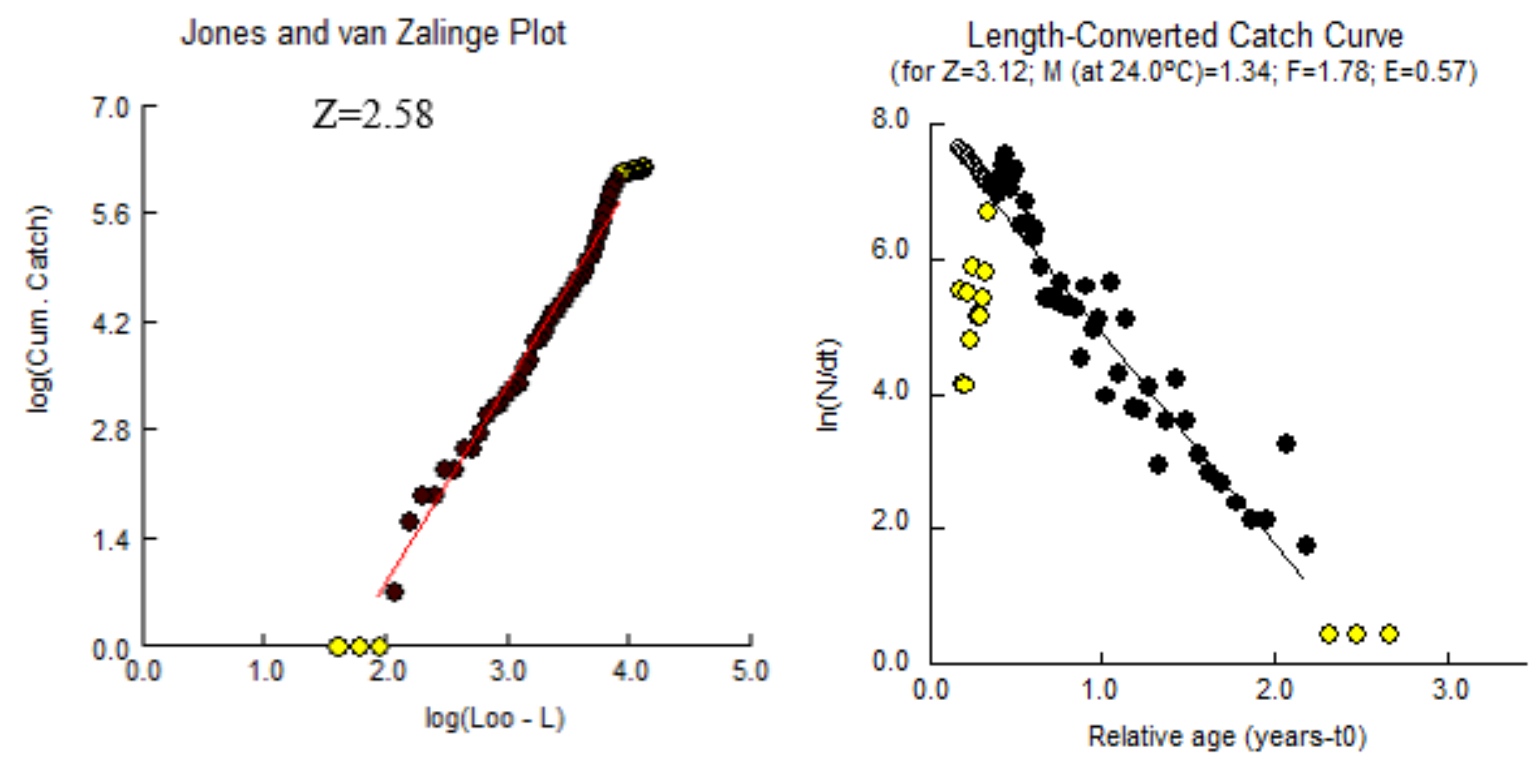

Figure 9: a) Jones an Zalinge and b) Length-converted catch curve plots estimating mortality coefficients. 


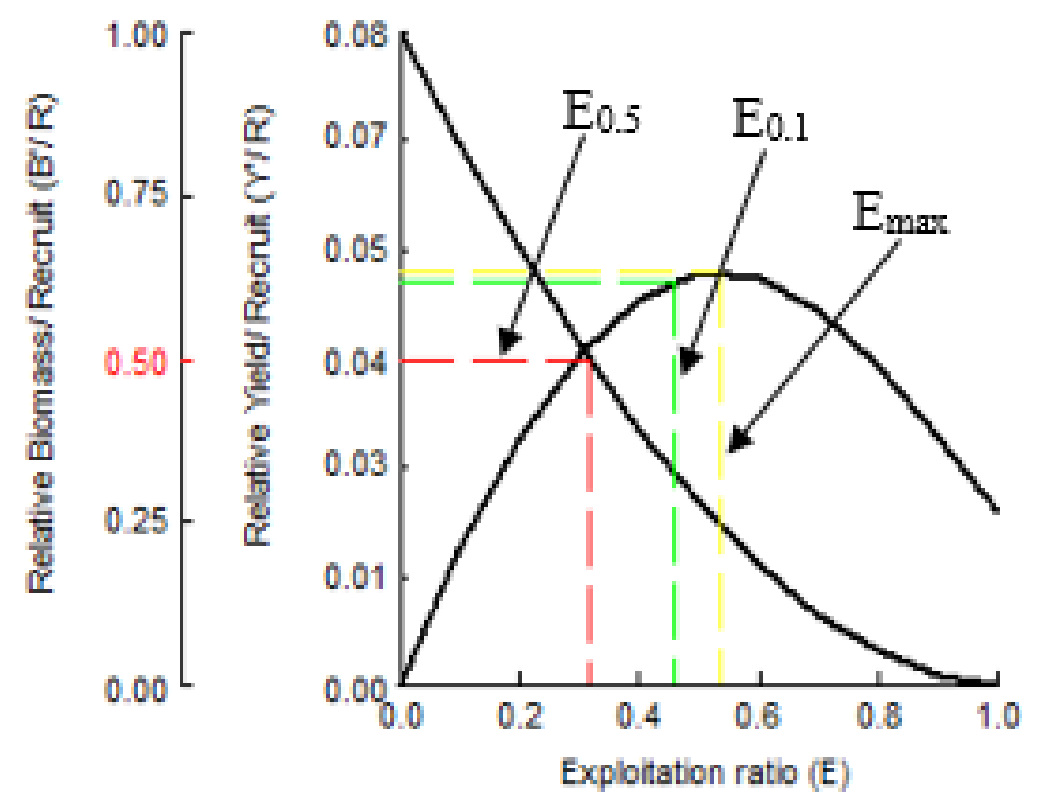

Figure 10: Beverton \& Holt's relative yield per recruit and average biomass per recruit models, showing levels of yield indices: $E_{0.5^{-}}$optimum sustainable yield, $E_{0.1^{-}}$maximum economic yield and $E_{\max }$ - maximum sustainable yield.

\section{Discussion}

\section{Fish biology}

The findings of the present study showed significantly more males than females of C. carpio with sex ratio 1.66: 1 (male: female). The results are similar to those of Nyaboke et al. 2014 who reported sex ratio of 1.63: 1 (male: female) for C. carpio in the Lake Naivasha. The predominance of males in this study is attributed to the gear type used capturing smaller fish since males were significantly smaller than females. The overall condition factor of 1.05 in this study is in agreement with 1.05-1.23 reported by Nyaboke et al. 2014 in the same lake. In the present study, $C$. carpio exhibited higher mean length, body weight and condition during the September and October with the least values recorded in January of the same year. This observation could be attributed to the availability of more food materials after the long rains in May, considering the seasonality of Lake Naivasha. This coincided with the presence of many mature female fish during the months of September and October. The adult C. carpio in the length class of 56-60 cm TL recorded higher condition than juveniles of less than $30 \mathrm{~cm} \mathrm{TL}$, 
which was linked better forging tactics. The length at first maturity estimated for females (54.0 $\mathrm{cm})$ and males $(49.0 \mathrm{~cm})$ of $C$. carpio in this study was relatively higher than findings in the same lake by Ojuok et al. 2007 (36 cm TL for both sexes) and Nyaboke et al. 2014 (47 cm TL for both sexes). The size at maturity of fish is mostly influenced by the fishing effects and changes in environmental variables. Fish can adopt $r$-selected or $k$-selected strategy basing on the existing conditions in their habitats.

\section{Population parameters}

The growth coefficient $(K)$ of $1.05 \mathrm{yr}^{-1}$ for $C$. carpio reported in this study was the highest compared to all the previous studies conducted in Lake Naivasha. Ojuok et al. (2007) reported $K$ values of $0.81 \mathrm{yr}^{-1}$ in 2002, $0.70 \mathrm{yr}^{-1}$ in 2003, $0.87 \mathrm{yr}^{-1}$ in 2004 and $0.91 \mathrm{yr}^{-1}$ in 2005 . However, Oyugi et al. (2011) found $K$ value of $0.72 \mathrm{yr}^{-1}$ during the period 2008 and 2009 in the same lake. The high $K$ value reported in the present study is indicative of a fast-growing fish. According to Sparre and Venema (1998), faster growth is depicted by $K$ value equal to or greater than 1 . The growth of fish is strongly influeced by food availability, environmental conditions and fishing effects. The mortality rates estimated for C. carpio in Lake Naivasha was higher than those reported by other authors for the same fish in Lake Naivasha (Oyugi et al. 2011; Ojuok et al. 2007). Fishing mortality $(F)$ is primarily induced by the fishing effects on the stocks. However, natural fish mortality $(M)$ is caused by factors not associated with fishing; predation, competition, cannibalism, diseases, spawning stress, starvation and pollution stress (Yongo \& Outa, 2016). The overall asymptotic length ( $L \infty)$ of $73.5 \mathrm{~cm}$ TL estimated for $C$. carpio in this study were lower than those found by Ojuok et al., 2007 from the same lake, estimated at 82.6 $\mathrm{cm}$ in 2004 and $97.0 \mathrm{~cm}$ in 2005. The reduction in the asymptotic length attained by C. carpio in Lake Naivasha could be attributable to fishing effect and deteriorating lake conditions (Njiru et al. 2017). The exploitation rate $(E)$ of 0.57 was higher than optimum sustainable yield $\left(\mathrm{E}_{0.5}\right)$ of 0.32 , but not different from maximum sustainable yield $\left(\mathrm{E}_{\max }\right) 0.54$ and economic yield $\left(\mathrm{E}_{0.1}\right)$ of 0.46. Indicative of some demographic equilibrium. The length at first capture $\left(\mathrm{L}_{\mathrm{C} 50}\right)$ for $C$. carpio reported in the present study is lower than its length at first maturity $\left(\mathrm{L}_{\mathrm{M} 50}\right)$, suggesting that the gears are catching high proportions of immature fish. This in the long term could lead to growth overfishing, hence the need for gear regulation in protecting the fishery. These aspects of fish biology and population parameters are very useful in managing a fishery under exploitation. 


\section{References}

Adamek, J.A., \& Pistelok, F. (1991). Acceleration of sexual maturity of common carp Cyprinus carpio (L) through alternate rearing in ponds and under controlled conditions. Acta Hydrobiologica, 33, 87-98.

Berverton, R.H., \& Holt, S.J. (1966). Manual of methods for fish stock assessment. Part II. Tables of yield function. FAO Fish Biology Technical paper, 38, 10 (version 1): 1-67.

Donkers, P.D. (2004). Age, Growth and Maturity of European Carp (Cyprinus carpio ) in Lakes Sorell and Crescent. Technical Report No.4 Inland Fisheries Service, Hobart, 18 p.

Elder, H.Y., Garrod , D.J., \& Whitehead, I.(1971). A natural hybrid of T. nigra and T. leucostictus from Lake Naivasha, Kenya. Journal of the Linnean Society of London (Zoology), 3: 103-106.

Froese, R., \& Pauly, D. 2002. "Fishbase: Species summary for Cyprinus carpio" Fish Base.Fulton, T.W., 1911. The sovereignty of the sea. London Edinbur

Gayanilo, F. C., Sparre, P., \& Pauly, D. (1996). FAO-ICLARM stock assessment tools (FISAT), Rome (126 pp., +3 diskettes).

Hickley, P., Muchiri, M., Britton ,R., Boar, R.(2008). Economic gain versus ecological damage from the introduction of non-native fish: Case studies from Kenya. The Open Fish Science Journal 1: 36-46.

Hickley, P., Muchiri, M., Gichuru, N., Britton, R., Harper, D., Adams, C. \& Boar, R. (2004). Habitat degradation and subsequent fishery collapse in Lakes Naivasha and Baringo, Kenya. Ecohydrology Hydrobiology 4: 503 - 517.

Keyombe, J.L., Yasindi, W. A., \& Oyugi O. D. (2017). Comparative assessment of diet and condition factor of Cyprinus carpio and Oreochromis leucostictus in Lake Naivasha, Kenya. International Journal of Aquatic Biology 5: 228-235.

Kitaka, N., Harper, D.M., \& Mavuti, K.M.(2002). Phosphorus inputs to Lake Naivasha, Kenya, from it catchment and the trophic state of the lake. Hydrobiologia 488: 73-80.

Lowe, S., Browne, M., Boudjelas, S., \& De Poorter, M.(2000) . 100 of the World's Worst Invasive Alien Species a selection from the Global Invasive Species Database. Switzerland: IUCN, $12 \mathrm{p}$. 
Njiru, J., Waithaka, E., \& Aloo, P. A. (2017). An Overview of the Current Status of Lake Naivasha Fishery: Challenges and Management Strategies. The Open Fish Science Journal 10: 1-11.

Nyaboke, C.A., Kembenya, E.M., Ogello, E.O.,Githukia , C.M., Yasindi, A., Outa, N., \& Munguti, J.M. (2014). Length-weight relationship and condition factor of common carp, Cyprinus carpio in Lake Naivasha, Kenya. International journal of current research, 6(9), 8286-8292.

Ojuok, J.E., Njiru, M., Mugo, J., Morara, G., Wakwabi, E., \& Ngugi,C. (2007). Increased dominance of common carp, Cyprinus carpio (L): the boon or the bane of Lake Naivasha fisheries? African Journal of Ecology 46: 445-448.

Oyugi, D.O., Cucherousset, J., Ntiba, M.J., Kisia, S.M., Harper,D.M.,\& Britton, J.R. (2011). Life history traits of an equitorial Common carp, Cyprinus carpio popolation in relation to thermal influences on invasive populations. Fish Res. 110:92-97.

Pauly, D. \& Munro J. L. (1984). Once more on growth comparison in fish and invertebrates. Fish Bytes 2, 21.

Pauly, D. (1980) On the interrelationship between natural mortality, growth parameters, mean environmental temperature in 175 fish stock. J. Cons. Int. Explor. Mer. 39, 175-92.

Pauly, D. (1987) A review of the ELEFAN system for analysis of length-frequency data in fish and aquatic invertebrates. In: Proceedings, Length-based Methods in Fisheries Research ICLARM Conference 13, 486 (eds D. Pauly \& G. R. Morgan) pp. 7-34.

Pauly, D., Ingles, J. \& Neal, R. (1984) Application to shrimp stocks of objective methods for the estimation of growth, mortality and recruitment-related parameters from lengthfrequency data (ELEFAN I and II). In Penaeid shrimps - their biology and management(p.220-234),J.A. Gulland and B.I. Rothschild (ed.), Fishing News Books, Farnham, England, 312 p.

Rahman, M.S., Han, J.C., Park, J., Lee, J.H., Eo, S.K., \& Chae , J.S. (2006). Prevalence of brucellosis and its association with reproductive problems in cows in Bangladesh. Vet. Rec, 159: 180-182.

Sparre, P. \& Venema, S.C. 1998. Introduction to tropical fish stock assessment, Part 1-Manual FAO Fish Tech. Pap. 306-1 rev. 2. 385 p. 
Vilizzi, L., Copp, G.H. (2017). Global patterns and clines in the growth of common carp Cyprinus carpio. J Fish Biol.91:3-40.

Vilizzi, L., Tarkan, A.S. (2015). Experimental Evidence for the Effects of Common Carp (Cyprinus carpio L., 1758) on Freshwater Ecosystems: A Narrative Review with Management Directions for Turkish Inland Waters. LimnoFish. 1, 123-149.

Winker, H., Weyl, O.L.F, Booth, A.J., \& Ellender, B.R. (2011). Life history and population dynamics of invasive common carp, Cyprinus carpio, in a large turbid African impoundment. Mar Freshw Res 62:1270-1280.

Yongo, E., \& Outa, N. (2016). Growth and population parameters of Nile tilapia, Oreochromis niloticus (L.) in the open waters of Lake Victoria, Kenya. Lakes \& Reservoirs: Research \& Management, 21(4), 375-379. https://doi.org/10.1111//re.12154.

Yongo, E., Agembe, S., Outa, N \& Owili, M. (2018). Growth, mortality and recruitment of Nile perch (Lates niloticus) in Lake Victoria, Kenya. Lakes and Reservoirs: Research and Management, 1-7. 